\title{
CORRELATION BETWEEN SALIVARY BIOCHEMICAL STRESS INDICATORS AND PSYCHOLOGICAL INDICATORS
}

\author{
Danijel Crnković, Mirna Peco and Josipa Gelo
}

Department of Psychiatry, Sestre milosrdnice University Hospital Centre, Zagreb, Croatia

\begin{abstract}
SUMMARY - Saliva is a complex body fluid that has various functions in the oral cavity. Central nervous system has the most important role in regulating salivation. Saliva as a sample is suitable for simplicity of sampling and because it contains analytes in the free active form. Stress is a condition in which the internal (psychophysical) balance of the body is disturbed. It activates the hypothalamicpituitary axis, so salivary cortisol is a free cortisol indicator that correlates well with its serum value and reflects the free fraction that is biologically active. At the same time, stress conditions stimulate the sympathetic neuronal system causing change in the secretion of salivary $\alpha$-amylase from salivary glands. The hypothesis of this study was that students with daily intensive physical activity are exposed to chronic stress compared to other students who have minimal physical activity. The study included 54 healthy volunteers, students of the University of Zagreb, divided into two groups. One volunteer group consisted of physically active volunteers $(n=27)$ from the Faculty of Kinesiology (FK), and the other group consisted of physically inactive volunteers $(n=27)$ from other faculties (OF). The subjects were first administered a psychological test that consisted of two questionnaires, Quality of Life Questionnaire and Questionnaire of Stressful Styles, and then underwent sampling of saliva. By comparing biochemical and psychological indicators in relation to stress, it was concluded that the two groups of students were equalized and that there was no objective support for either group to be considered exposed to chronic stress. Despite the substantial differences in physical activity, there was no difference between the two student populations.
\end{abstract}

Key words: Saliva; Stress, Physiological; Stress, Psychological; Nervous System; Hydrocortisone; Amylases; Salivary Glands; Exercise; Psychological Tests; Surveys and Questionnaires

\section{Introduction}

Stress is a condition in which an internal (psychophysical) balance of the body is disturbed, and which requires additional effort to adapt. Stress stimulus (stressor) is every stimulus that brings an individual into stress. A stressful situation can be a stressful stimulus for an individual confronted with such stimuli. However, if a stressful reaction occurs, it depends on whether the individual perceives the situation as en-

Correspondence to: Danijel Crnković, MD, Department of Psychiatry, Sestre milosrdnice University Hospital Centre, Vinogradska c. 29, HR-10000 Zagreb, Croatia

E-mail: crnkovic.danijel@gmail.com

Received October 16, 2017, accepted January 31, 2018 dangering or not. Stressful experiences are those that occur under the influence of stressful stimuli. Changes that occur in the body under the influence of stress can, under certain conditions, cause false organic disorders called psychosomatic disorders and psychosomatic diseases ${ }^{1}$.

Stress triggers two biological systems, the hypothalamic-pituitary-adrenocortical axis (HPA) and the sympatho-adrenomedullary axis (SAM). Activation of HPA results in increased secretion of the hormone cortisol $^{2}$. Salivary concentrations of cortisol are related to the free form and they are well correlated with serum $\mathrm{cortisol}^{3}$. There are several types of stress that are classified according to the duration and frequency into acute, chronic, psychological and physical stress. Acute 
stress is the most common form of pressure and demand from the immediate past, current environmental demands, and pressures and expectations from the near future. Chronic stress is exposure to stressful and exhausting situations over a longer period, especially at work or in family environment. It is often associated with poor socioeconomic status, social isolation, inability to control and influence the events, self-confidence and suicidal thoughts ${ }^{4}$. Emotional or chronic stress is very dangerous and it ranks second in causing the disease. 'Burn out' is a complete emotional exhaustion syndrome due to work hardships (ineffective performance at work $)^{2,5}$. Psychic stress is also present when writing an exam. Many studies have investigated experiencing stress induced by examinations and its consequences on the cellular immunity functioning. During the test period, respondents experience a higher degree of stress with a significant reduction in the function of different cellular immunity indicators ${ }^{6}$. Physical stress occurs when the body is in immediate danger, e.g., physical combat, traffic accident, wounding, life-threatening event (struggle for survival), or cycling, running, and exposure to cold ${ }^{5}$. At present, several salivary biomarkers such as salivary cortisol, salivary alpha-amylase (sAA), salivary secretory immunoglobulin A ( $\operatorname{IgA}$ ) and dehydroepiandrosterone concentrations are currently being used in stress research. Salivary biomarkers are more popular in stressrelated research because it is proven to be better than testing biomarkers from the blood ${ }^{7}$.

The advantages are that the method is noninvasive, eliminating the risk of needle puncture while collecting blood, and causing minimal discomfort to the individual. sAA is a digestive hormone, synthesized in acinar cells, stored in granules and released into saliva in response to neurohormone stimulation. The sAA concentration is independent of the amount of saliva produced. Significantly, the concentration of this enzyme in saliva is proportional to the IgA concentration and inversely proportional to stress level. sAA is used as a stress marker, and is highly susceptible to stressful situations including psychic stress ${ }^{7}$.

Excretion of sAA is associated with psychoneuroendocrine response to stress rather than the salivation rate and age. sAA is one of the richest components in the saliva and makes $10 \%$ to $20 \%$ of total protein content. Previous research demonstrated a link between sAA secretion and exposure to stress condition ${ }^{8,9}$. Generally, cortisol has a typical circadian rhythm of higher values in the morning and lower values in the evening ${ }^{10}$. Salivary cortisol is an excellent indicator of free cortisol, correlates well with serum value, and reflects the free fraction of cortisol that is biologically active; thus, the adrenocortical function of serum cortisol is better shown by measuring salivary cortisol concentrations ${ }^{11}$. Therefore, salivary cortisol is often used in stress assessment. Salivary cortisol in comparison to total cortisol is by $1 \%$ to $2 \%$ lower; cortisol concentration in the saliva is low $(1-10 \mu \mathrm{g} / \mathrm{L})$ due to the presence of $11 \beta$-hydroxysteroid dehydrogenase, which oxidizes $30 \%$ of free cortisol enzymes in cortisone ${ }^{12}$.

Many factors such as neuropeptides, neurotransmitters, opioids, growth factors, cytokinesis, adipokinesis, and battery ligands modulate the release of adrenal glucocorticoids independently of pituitary adrenocorticotropic hormone $(\mathrm{ACTH})^{13}$. Adrenal cortisol release during circadian ascension and stress response are under the control of ACTH and preganglionic sympathetic neurons ${ }^{12,14}$.

The aim of this scientific work was to measure the basal morning concentration of $\alpha$-amylase and cortisol in the saliva, to examine differences in concentrations and test results related to chronic physical stress between students with regular daily and intensive physical exercises as a mandatory part of their classes and students of various faculties with no regular physical activity or only occasional weekly physical activity, possibly exposed to greater mental stress. Results of measuring these markers were correlated with the results of psychological testing. Finally, our aim was to examine whether intensive physical activity was a feature of chronic stress as compared with the physically inactive group, and whether the hypothesis could be confirmed by the concentration of salivary biochemical markers or by psychological testing of readiness for stress.

\section{Subjects and Methods}

\section{Subjects}

The study included 54 healthy volunteers, students from the University of Zagreb, divided into two groups: one group consisting of physically active volunteers $(n=27)$ from the Faculty of Kinesiology (FK), and the other group of physically inactive volunteers $(n=27)$ from the Faculty of Law, Faculty of Pharmacy and Biochemistry, Faculty of Dentistry, Faculty of Vet- 
erinary Medicine, Faculty of Food Technology and Biotechnology, Faculty of Mining and Geology and Petroleum Engineering, Faculty of Catholic Science, Faculty of Organization and Informatics, Faculty of Humanities and Social Sciences and Faculty of Agriculture $(\mathrm{OF})$. The two groups were matched by gender, with 15 males and 12 females in the group of physically active subjects, and 14 males and 13 females in the other group of physically inactive subjects, age range 19 to 26 years. The samples were marked with codes, and the only data recorded were age and gender of the respondent, and time and date of sampling. The research was approved by the Ethics Committee of the Faculty of Pharmacy and Biochemistry in Zagreb. The informed consent form contained the purpose, description, course and aim of the research, and the respondents were further informed verbally on the informed consent, then they read it themselves and signed.

\section{Clinical trials and diagnostic procedures}

All study subjects first completed a psychological test that, in a series of questions, measured psychometrically their way of dealing with stressful situations in life. Psychological test was evaluated by a clinical psychologist from Sestre milosrdnice University Hospital Centre. Then saliva was collected in a nonaggressive way by use of a standard double-tube system (Sarsted, Germany).

\section{Laboratory diagnostic workup}

Study subjects were asked not to drink, eat, chew, smoke, or monitor their teeth for half an hour before sampling. Saliva samples were obtained between 10.00 and $12.00 \mathrm{am}$. Sampling was carried out by placing a sterile pad directly from the small tube in the mouth, then by chewing procedure, in a nonaggressive manner, the pad was filled with saliva for 1 minute and returned directly from the mouth to the tube. The tubes were subjected to centrifugation at a standard centrifuge at $3000 \mathrm{rpm}$ for 3 minutes (in a centrifuge of 10$\mathrm{cm}$ diameter), which caused separation of liquid (saliva) from the soaked pad. A saliva sample of $1.1 \pm 0.3$ $\mathrm{mL}$ was obtained by centrifugation. Larger test tubes with the contents of saliva and remains of any broken parts of the cells and other particles packed in the narrow conical end of the tube were stored in a refrigera- tor at +4 to $+8{ }^{\circ} \mathrm{C}$ until analysis. The concentration of cortisol and sAA in saliva was analyzed by enzyme immunoassay at Clinical Institute of Chemistry, Sestre milosrdnice University Hospital Centre. The concentration of $\alpha$-amylase in the saliva was determined by the commercial assay Alpha Amylase Saliva ELISA E130607AB (Euroimmun, Lübeck, Germany), which contains all reagents and standard solutions prepared in accordance with the In Vitro Diagnostic (IVD) Directive for sAA determination in saliva ${ }^{15}$. The concentration of cortisol in the saliva was determined by the commercial test Cortisol Saliva ELISA E131106BK (Euroimmun, Lübeck, Germany) containing all reagents and standard solutions prepared in accordance with the IVD Directive for determination of cortisol in saliva ${ }^{16}$.

\section{Psychological measuring instruments}

An adaptive version of the questionnaire dealing with stressful situations was applied for coping strategy (Coping Orientation to Problems Experienced, $\mathrm{COPE})^{17}$. This questionnaire was adapted to cultural conditions of this area ${ }^{6}$. The so-adapted COPE questionnaire consists of 71 particles making up $17 \mathrm{em}-$ pirically derived scales, 15 of which are taken from the original (COPE) questionnaire, while the specific answers of the respondents in this area made two additional scales called the scaling scale and the emotional depression scale. The task of the respondent was to answer what they generally felt and how they reacted when they were in stressful situations. The COPE questionnaire consists of 17 scales that imply different coping strategies. Combining styles with a common way of responding to stress was applied in the research by Hudek-Knežević and Kardum ${ }^{7}$, where they also assessed the respondents facing psychological stress ${ }^{18}$. Styles of stress-focused stress, emotions (emotional approach) and avoidance strategies (denying and running away from stress, i.e. stressors) are different. The WHOQOL-BREF questionnaire presents a shortened version of the WHOQOL-100 questionnaire produced by the World Health Organization (WHO) for the purpose of assessing the quality of life. WHOQOL-BREF was compiled using and analyzed by WHOQOL-100 pilot study data. Twenty-five particles were selected from the original questionnaire, one particle for the quality of life as a whole and for gen- 
eral health. The questionnaire in its entirety contains 26 particles. Psychometric research has shown that WHOQOL-BREF is a reliable and valid instrument. Perception of the quality of life, perceived in each of the 4 domains of the questionnaire, is particularly relevant (physical health, psychological state, social relations, and the environment), where the scale is directed positively, which means that a greater number of points represents a higher quality of life. The questionnaire consists of 26 questions and each question points to the Likert scale 1 (worst) to 5 (best). After transformation of the points in two steps, the points for each domain are within the 0 to 100 scale. In this study, a valid Croatian version of the questionnaire was used, which was tailored to this group of respondents. This questionnaire assesses perception of an individual in the context of his/her culture, personal goals, standards, and concerns ${ }^{19,20}$.

\section{Statistical methods}

Excel 2010, Microsoft Office (Microsoft, USA) and MedCalc v. 12.2.1.0 (MedCalc Software, Mariakerke, Belgium) were used on statistical data processing. Characteristics of data sets were presented by the method of descriptive analysis, KolmogorovSmirnov statistical test was employed to examine the normality of data distribution. If data distribution did not follow gaussian distribution, nonparametric tests were used and data described by median and range of the values measured. Correlation was assessed by use of Pearson or Spearman parametric or nonparametric tests with the corresponding coefficient of correlation (r) and statistical significance (p). Correlation coefficients were interpreted according to Colton. Parametric t-test for independent samples or non-parametric Mann-Whitney test was used to compare the variables depending on the normality of distribution. All results were interpreted at the level of statistical significance of $\mathrm{p}<0.05$.

\section{Results}

Table 1 shows the results obtained by determining sAA and cortisol in the FK and OF groups of students. Statistical data including mean values of sAA and cortisol concentrations and associated standard deviation (SD), median, minimum and maximum, number of subjects in each group, and age of subjects were presented. All results were interpreted at the level of statistical significance of $p<0.05$. The $p$ values obtained showed normal distribution of all variables except for life expectancy.

In Table 2, the results of the respondents' answers to the part of the psychological test, Questionnaire of Stressful Styles, are presented. The table shows data for FK and OF groups, including age of the respondents, number of the respondents in each group, mean value, $\mathrm{SD}$, median, minimum, maximum and normality of distribution of the responses to the Questionnaire of Stressful Styles psychological test for each group. The results obtained were interpreted at the level of statistical significance of $p<0.05$. The $p$ values obtained showed normal distribution of all variables except for age and avoidance as the style of coping with stress in the OF group.

Table 3 shows the results of the respondents' responses to the part of the Quality of Life Questionnaire psychological test. The table shows total number of the respondents, age of the respondents, mean value of the responses with associated SD, median, minimum, maximum and $\mathrm{p}$ value for each group. The results obtained were interpreted at the level of statistical significance of $p<0.05$. The $p$ values obtained showed normal distribution of all variables except for life expectancy.

After determining concentrations of sAA and cortisol, their values were compared to see if there was a difference between the groups. The concentrations of sAA were compared between the groups ( $p=0.697$ ), between women and men of the FK group ( $p=0.008)$, and between all female and all male subjects from both groups $(p=0.033)$. Analysis of these results yielded a statistically significant difference in sAA concentrations between men and women in FK group and between all men and women of both groups. Cortisol concentrations were compared between the groups regardless of gender $(p=0.426)$, between women from FK group and those from OF group $(\mathrm{p}=0.241)$, and between men from FK group and those from OF group $(p=0.930)$. Statistically, results were interpreted at the $\mathrm{p}<0.05$ level, yielding no statistically significant difference in cortisol values between the groups. The results of these measurements are illustrated in Figures 1-6.

The results obtained by solving the Questionnaire of Stressful Styles and Quality of Life Questionnaire psychological tests were compared between FK and 
Table 1. Results of $s A A$ and cortisol concentrations

\begin{tabular}{|c|c|c|c|c|c|c|c|c|c|c|c|c|c|c|}
\hline & \multicolumn{7}{|c|}{ FK } & \multicolumn{7}{|c|}{$\mathrm{OF}$} \\
\hline & n & $\chi \pm \mathrm{SD}$ & Median & Min & Max & $25^{\text {th }}-75^{\text {th }}$ & $\mathrm{p}$ & $\mathrm{n}$ & $\chi \pm \mathrm{SD}$ & Median & Min & Max & $25^{\text {th }}-75^{\text {th }}$ & $\mathrm{p}$ \\
\hline Age (yrs) & 27 & $\begin{array}{l}21.4 \\
\pm 1.31\end{array}$ & 21.0 & 20.0 & 24.0 & $20.3-22.0$ & 0.226 & 27 & $\begin{array}{l}23.0 \\
\pm 1.56\end{array}$ & 23.0 & 19.0 & 26.0 & $23.0-24.0$ & 0.005 \\
\hline $\mathrm{sAA}(\mathrm{U} / \mathrm{mL})$ & 27 & $\begin{array}{l}132.1 \\
\pm 136.76\end{array}$ & 101.8 & 2.9 & 439.3 & $3.2-222.9$ & 0.159 & 27 & $\begin{array}{l}120.5 \\
\pm 72.08\end{array}$ & 120.9 & 15.3 & 324.4 & 78.4-165.6 & 0.146 \\
\hline Cortisol (ng/mL) & 27 & $\begin{array}{l}2.6 \\
\pm 1.39\end{array}$ & 2.8 & 0.5 & 6.0 & $1.6-3.7$ & 0.791 & 27 & $\begin{array}{l}3.0 \\
\pm 1.52 \\
\end{array}$ & 2.8 & 0.2 & 5.6 & $2.1-4.3$ & 0.645 \\
\hline
\end{tabular}

$\mathrm{FK}=$ students from the Faculty of Kinesiology; $\mathrm{OF}=$ students from other faculties; $\mathrm{n}=$ number of respondents; $\chi=$ mean value; SD = standard deviation; Min $=$ minimum; Max $=$ maximum; $25^{\text {th }}-75^{\text {th }}=$ variable size range from $25^{\text {th }}$ to $75^{\text {th }}$ percentile; $\mathrm{p}=$ distribution normal ity; sAA = salivary $\alpha$-amylase

Table 2. Results of responses to the Questionnaire of Stressful Styles

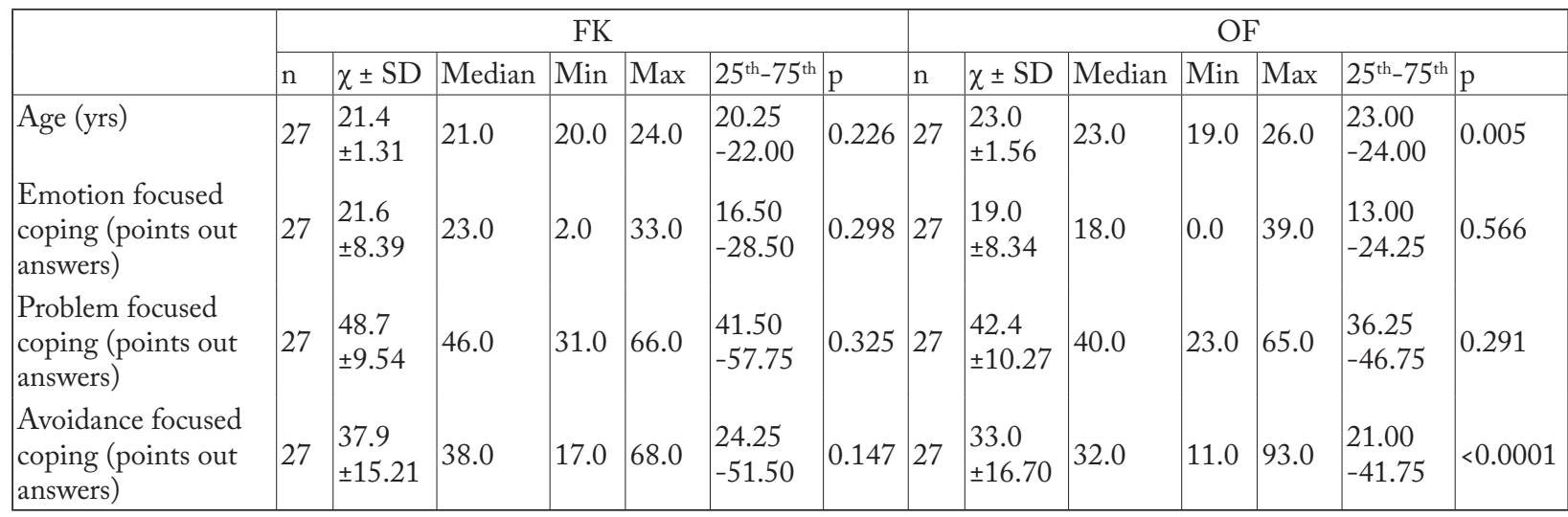

FK = students from the Faculty of Kinesiology; $\mathrm{OF}=$ students from other faculties; $\mathrm{n}=$ number of respondents; $\chi=$ mean value; $\mathrm{SD}=$ standard deviation; Min $=$ minimum; Max $=$ maximum; $25^{\text {th }}-75^{\text {th }}=$ variable size range from $25^{\text {th }}$ to $75^{\text {th }}$ percentile; $\mathrm{p}=$ distribution normal ity of variables (Emotion focused coping, Problem focused coping, Avoidance focused coping) representing responses to the questionnaire on the quality of life scored on a scale of $0-4$

Table 3. Results of responses to the Quality of Life Questionnaire

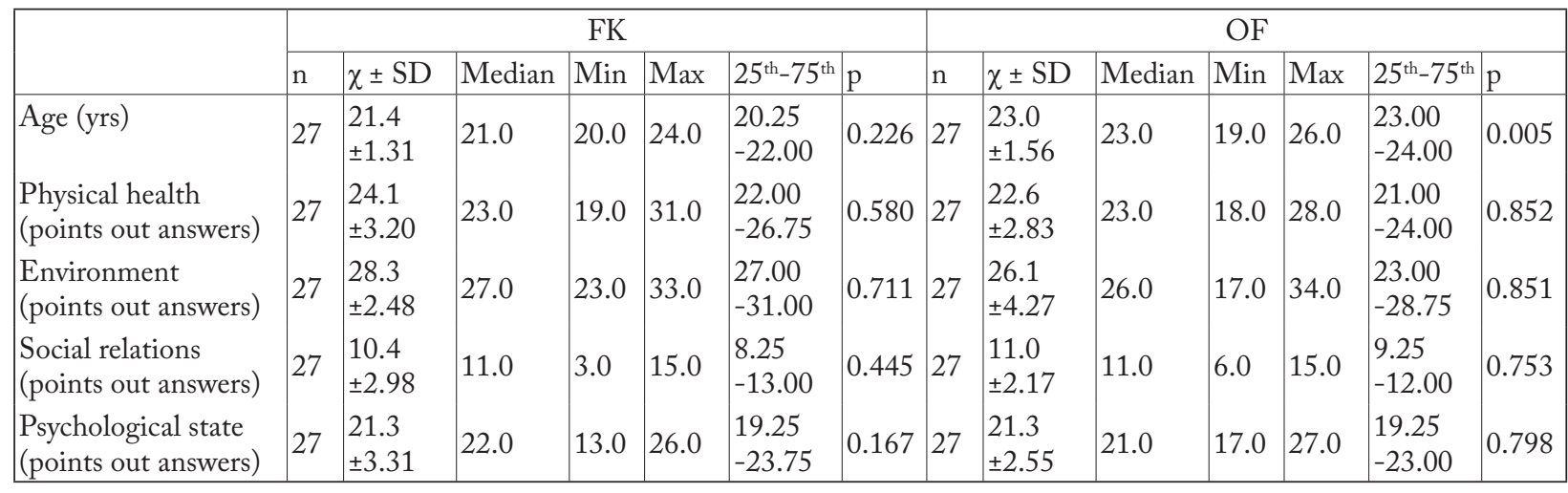

$\mathrm{FK}$ = students from the Faculty of Kinesiology; $\mathrm{OF}=$ students from other faculties; $\mathrm{n}=$ number of respondents; $\chi=$ mean value; $\mathrm{SD}=$ standard deviation; Min = minimum; Max $=$ maximum; $25^{\text {th }}-75^{\text {th }}=$ variable size range from $25^{\text {th }}$ to $75^{\text {th }}$ percentile; $p=$ distribution normality of variables (physical health, environment, social and psychological state) representing responses in the questionnaire on the quality of life rated on a scale of 1-5 


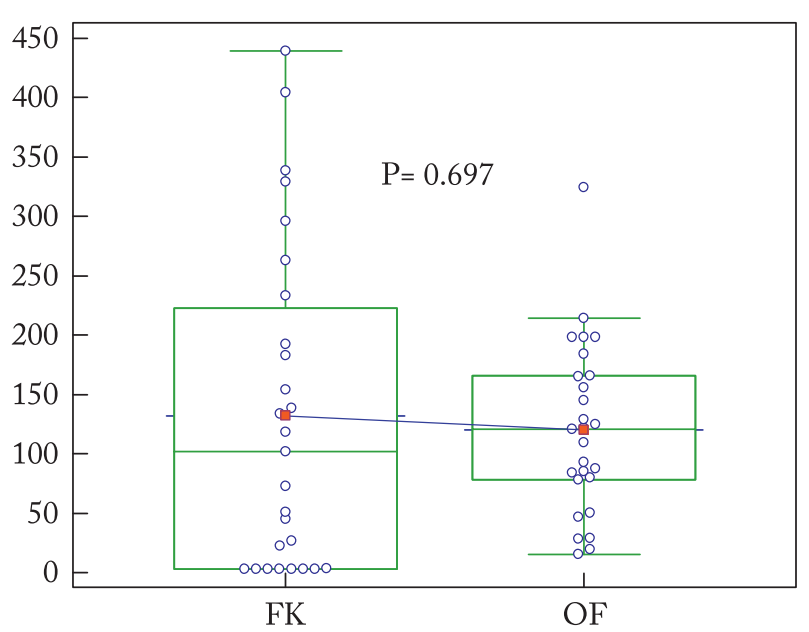

Fig. 1. Comparison of $s A A$ concentration between $F K$ and $O F$.

sAA = salivary $\alpha$-amylase; FK = students from the Faculty of Kinesiology; OF = students from other faculties; $\mathrm{p}$ = distribution normality; central green square denotes $25^{\text {th }}$ to $75^{\text {th }}$ percentile, central line in the square denotes median, mean is marked with red dot, horizontal lines extend from the minimum to the maximum excluding outliers, which are displayed as separate points, blue lines are central values of the two groups

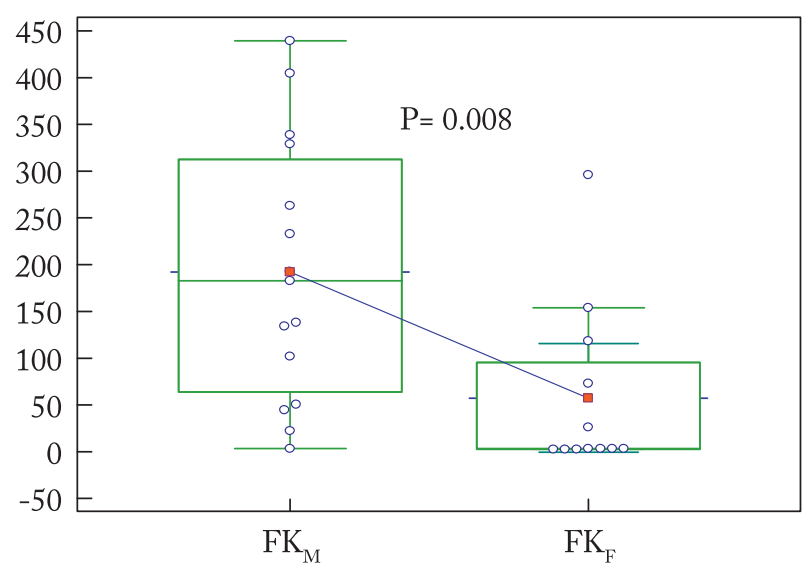

Fig. 2. Comparison of $s A A$ concentration between genders in FK group.

sAA = salivary $\alpha$-amylase $; \mathrm{FK}_{\mathrm{M}}=$ male students from the Faculty of Kinesiology; $\mathrm{FK}_{\mathrm{F}}=$ female students from the Faculty of Kinesiology; $\mathrm{p}=$ distribution normality; central green square denotes $25^{\text {th }}$ to $75^{\text {th }}$ percentile, central line in the square denotes median, mean is marked with red dot, horizontal lines extend from the minimum to the maximum excluding outliers, which are displayed as separate points, blue lines are central values of the two groups

OF groups using t-test. Statistically significant values were obtained for the Style Problem Confrontation $(\mathrm{p}=0.023)$ and for the Environment $(\mathrm{p}=0.023)$.

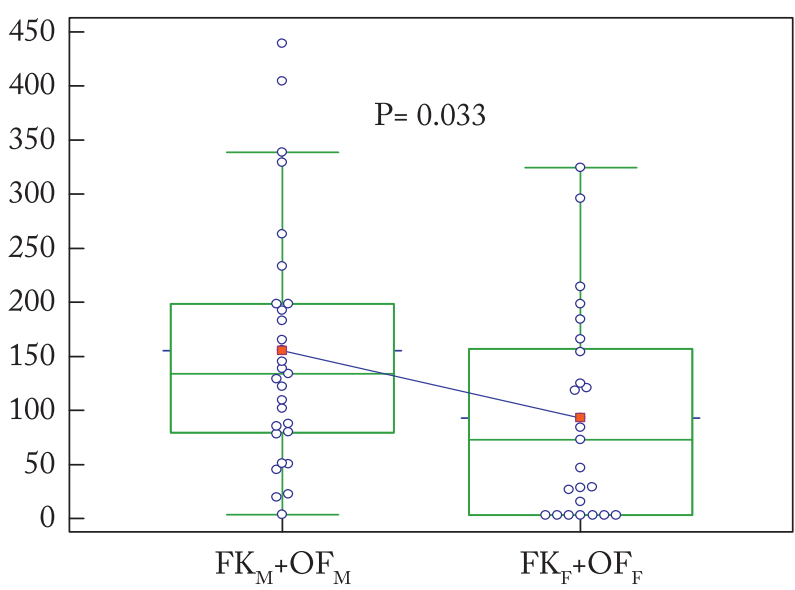

Fig. 3. Comparison of $s A A$ concentration between men and women from both groups.

sAA = salivary $\alpha$-amylase; $\mathrm{FK}_{\mathrm{M}}+\mathrm{OF}_{\mathrm{M}}=$ all male respondents; $\mathrm{FK}_{\mathrm{F}}$ $+\mathrm{OF}_{\mathrm{F}}=$ all female respondents; $\mathrm{p}=$ distribution normality; central green square denotes $25^{\text {th }}$ to $75^{\text {th }}$ percentile, central line in the square denotes median, mean is marked with red dot, horizontal lines extend from the minimum to the maximum excluding outliers, which are displayed as separate points, blue lines are central values of the two groups

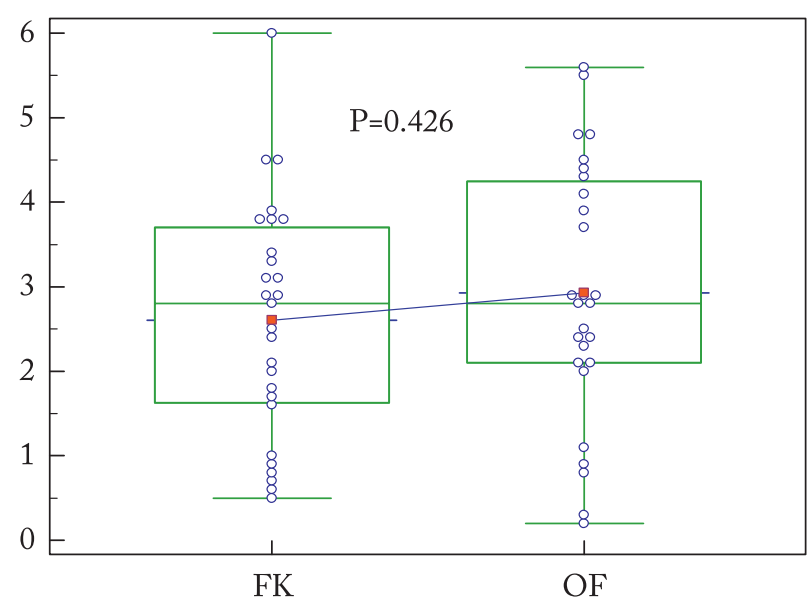

Fig. 4. Comparison of cortisol concentration between students from the Faculty of Kinesiology (FK) and students from other faculties (OF).

$\mathrm{p}=$ distribution normality; central green square denotes $25^{\text {th }}$ to $75^{\text {th }}$ percentile, central line in the square denotes median, mean is marked with red dot, horizontal lines extend from the minimum to the maximum excluding outliers, which are displayed as separate points, blue lines are central values of the two groups

Other results are shown in Table 4, with no statistically significant value recorded.

Figures 7-9 show correlations of sAA and cortisol between $\mathrm{KF}$ and $\mathrm{OF}$ groups and their correlation 


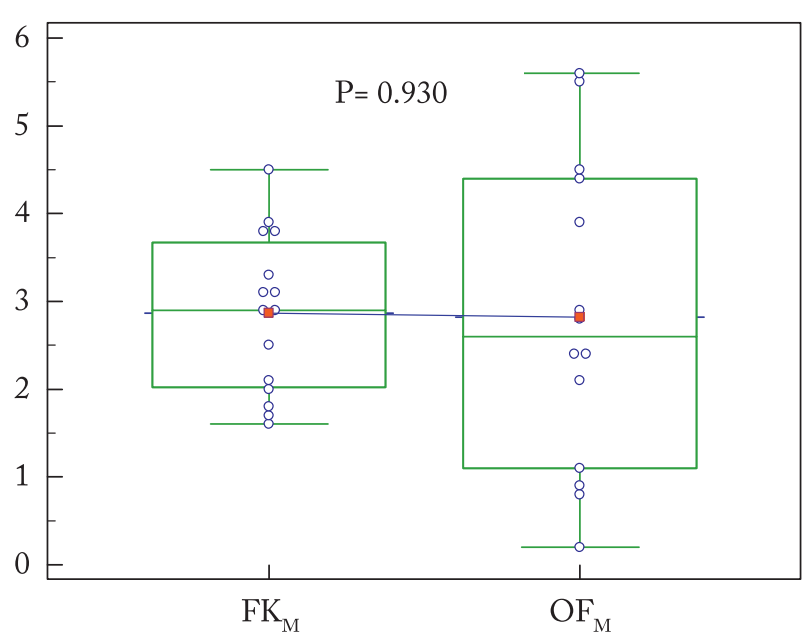

Fig. 5. Comparison of cortisol concentration between men from the two groups.

$\mathrm{FK}_{\mathrm{M}}=$ students from the Faculty of Kinesiology; $\mathrm{OF}_{\mathrm{M}}=$ students from other faculties; $\mathrm{p}$ = distribution normality; central green square denotes $25^{\text {th }}$ to $75^{\text {th }}$ percentile, central line in the square denotes median, mean is marked with red dot, horizontal lines extend from the minimum to the maximum excluding outliers, which are displayed as separate points, blue lines are central values of the two groups

within a single group by the mathematical linear regression model. According to the coefficient of correlation $r$ by Colton, sAA and cortisol showed only weak correlation in the OF group of students $(\mathrm{r}=-0.410)$. However, interpretation by statistical significance at $\mathrm{p}<0.05$ revealed the result to be statistically significant $(\mathrm{p}=0.03)$.

Considering psychological indicators, correlation was observed for individual variables according to the

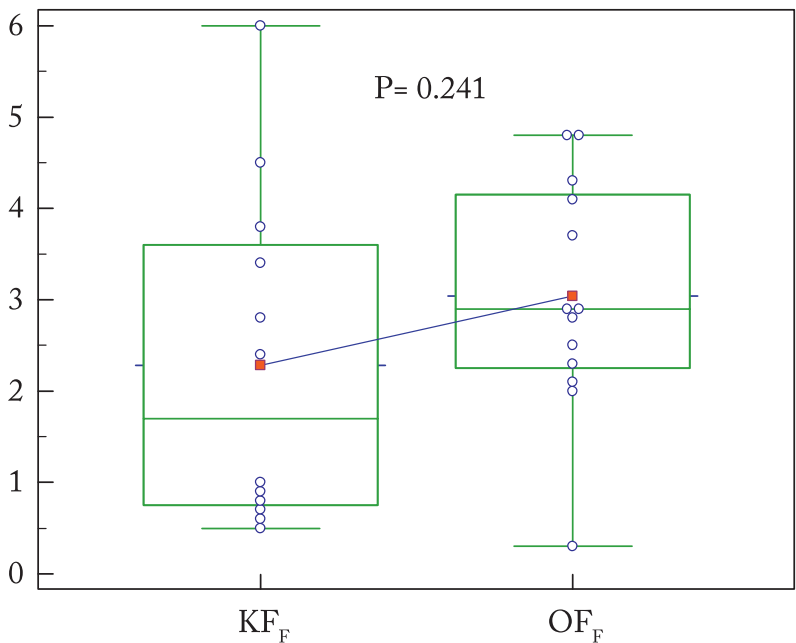

Fig. 6. Comparison of cortisol concentration between women from the two groups.

$\mathrm{KF}_{\mathrm{F}}=$ female students from the Faculty of Kinesiology; $\mathrm{OF}_{\mathrm{F}}=\mathrm{fe}-$ male students from other faculties; $p=$ distribution normality; central green square denotes $25^{\text {th }}$ to $75^{\text {th }}$ percentile, central line in the square denotes median, mean is marked with red dot, horizontal lines extend from the minimum to the maximum excluding outliers, which are displayed as separate points, blue lines are central values of the two groups

coefficient of correlation $r$ by Colton, but this correlation was weak. Weak correlation was obtained for the following variables: directed confrontation and physical health $(\mathrm{r}=0.447)$ in both FK and OF groups; in FK group for physical health and directed avoidance ( $\mathrm{r}=-$ 0.448 ), and for social relations and directed avoidance $(\mathrm{r}=-0.475)$; and in OF group for physical health and directed avoidance $(r=0.432)$. Moderate correlation

Table 4. Comparison of psychological tests between two groups of students using t-test

\begin{tabular}{|c|c|c|c|c|c|c|c|}
\hline \multirow[b]{2}{*}{ Strategies } & \multicolumn{3}{|c|}{ KF } & \multicolumn{3}{|c|}{$\mathrm{OF}$} & \multirow[b]{2}{*}{$\mathrm{p}$} \\
\hline & $\mathrm{n}$ & $\chi$ & SD & $\mathrm{n}$ & $\chi$ & SD & \\
\hline & \multicolumn{6}{|c|}{ Results of responses to the Questionnaire of Stressful Styles } & \\
\hline Problem focused coping & 27 & 21.6 & 8.39 & 27 & 19 & 8.34 & 0.023 \\
\hline Emotion focused coping & 27 & 48.7 & 9.54 & 27 & 42.4 & 10.27 & 0.253 \\
\hline \multirow[t]{2}{*}{ Avoidance focused coping } & 27 & $38^{*}$ & $\begin{array}{l}\text { Min17 } \\
\text { Max68 }\end{array}$ & 27 & $32^{*}$ & $\begin{array}{l}\text { Min11 } \\
\text { Max93 }\end{array}$ & $0.194^{*}$ \\
\hline & \multicolumn{6}{|c|}{ Results of responses to the Questionnaire of Quality of Life } & \\
\hline Physical health & 27 & 24.1 & 3.2 & 27 & 22.6 & 2.83 & 0.071 \\
\hline Psychological state & 27 & 28.3 & 2.48 & 27 & 26.1 & 4.27 & 0.964 \\
\hline Social relations & 27 & 10.4 & 2.98 & 27 & 11.0 & 2.17 & 0.468 \\
\hline Environment & 27 & 21.3 & 3.31 & 27 & 21.3 & 2.55 & 0.023 \\
\hline
\end{tabular}

$\mathrm{FK}=$ students from the Faculty of Kinesiology; $\mathrm{OF}=$ students from other faculties; $\mathrm{n}=$ number of respondents; $\chi=$ mean value; $\mathrm{SD}=$ standard deviation; $\mathrm{p}=$ distribution normality; *results were tested by Mann-Whitney nonparametric test 


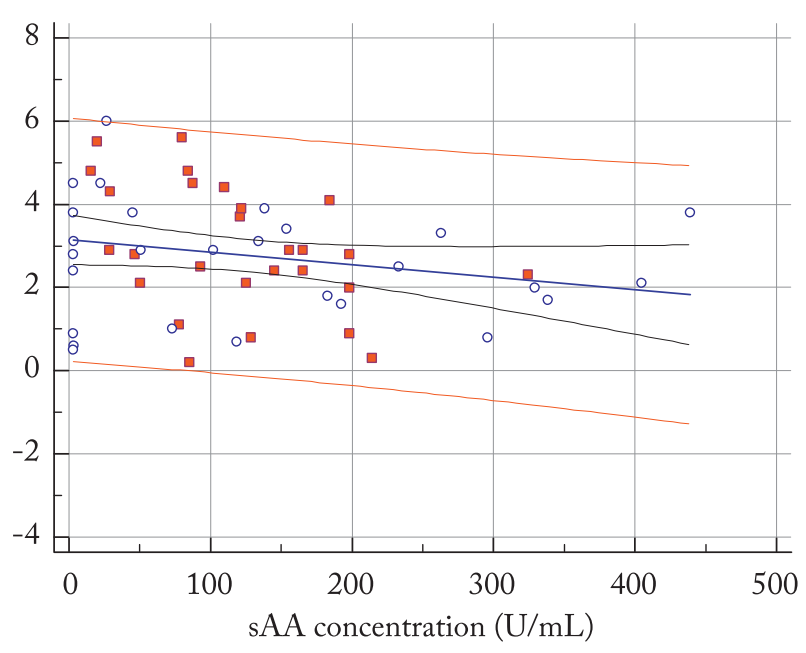

Fig. 7. Correlation of $S A A$ and cortisol between $K F(0)$ and $O F$ ( $\square$ ).

$\mathrm{r}=-0.225, \mathrm{p}=0.102 ; \mathrm{sAA}=$ salivary $\alpha$-amylase; $\mathrm{FK}=$ students from the Faculty of Kinesiology; $\mathrm{OF}=$ students from other faculties; orange lines represent the interval of predictability, purple lines confidence interval, and central blue line direction of regression

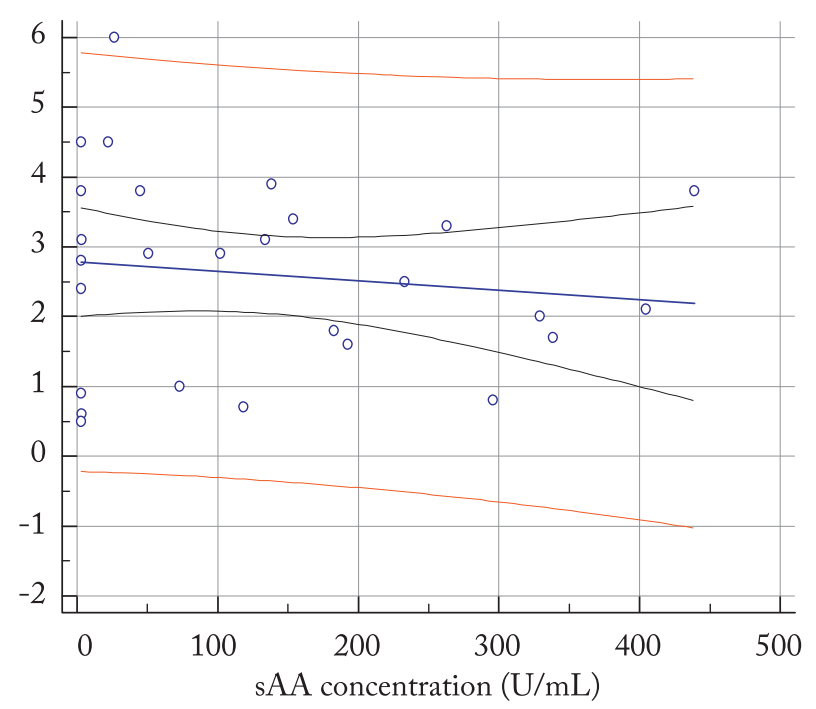

Fig. 8. Correlation of cortisol and $s A A$ in FK group.

$\mathrm{r}=-0.133, \mathrm{p}=0.507 ; \mathrm{sAA}=$ salivary $\alpha$-amylase; FK = students from the Faculty of Kinesiology; orange lines represent the interval of predictability, purple lines confidence interval, and central blue line direction of regression

was found for comorbid and psychological variables $(\mathrm{r}=+0.535)$ in $\mathrm{FK}$ group, and for age and problem avoidance in OF group ( $\mathrm{r}=-0.512)$.

There was no statistically significant correlation of sAA and cortisol with psychological indicators based

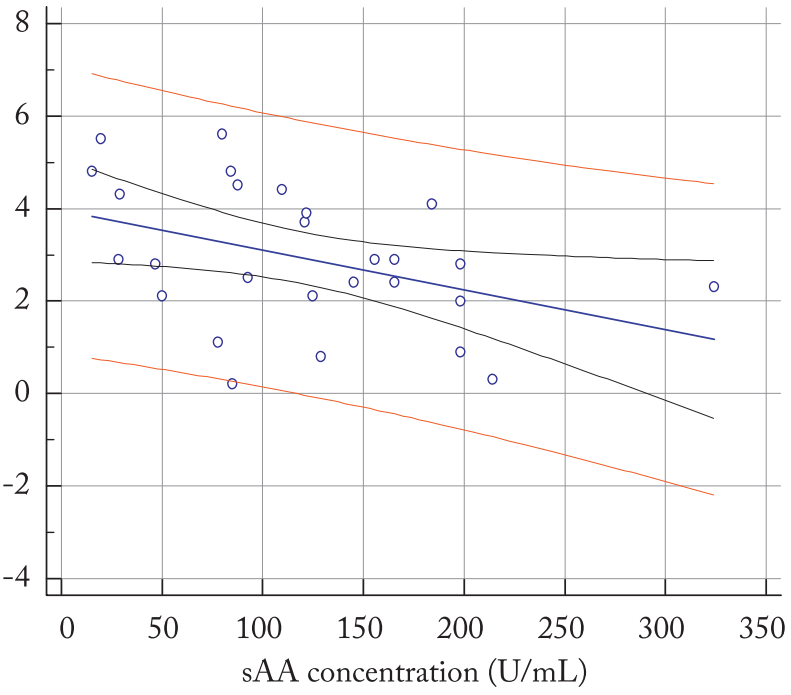

Fig. 9. Correlation of cortisol and $S A A$ in $O F$ group.

$\mathrm{r}=-0.410, \mathrm{p}=0.034 ; \mathrm{sAA}=$ salivary $\alpha$-amylase; $\mathrm{OF}=$ students from other faculties; orange lines represent the interval of predictability, purple lines confidence interval, and central blue line direction of regression

on the response to the two psychological tests, Questionnaire of Stressful Styles and Quality of Life Questionnaire.

\section{Discussion}

In the past ten years, saliva has become a very popular laboratory sample for simple and noninvasive sampling, making it a rapid and inexpensive method as compared with other samples, which can be carried out under supervision of any educated person ${ }^{21}$. sAA and salivary cortisol were selected as markers to estimate the level of stress because many studies have shown their promising benefit ${ }^{7}$. Salivary cortisol is an excellent cortisol indicator that correlates well with its serum value and reflects the free fraction of cortisol that is biologically active; measuring the concentration of salivary cortisol shows adrenocortical function better than serum cortisol. Salivary cortisol is therefore often used in stress assessment. Search for a similar noninvasive marker of mental and physical stress that would be an indicator of SAM activation yielded best results for sAA concentration, which shows disruption in stressful circumstances. The secretion of sAA, an enzyme important for the digestion of carbohydrates, is strongly neurohumorally monitored by the sympathet- 
ic nervous system. Therefore, the assumption is that sAA reflects the sympathetic nervous system activity. This research was conducted at the Faculty of Pharmacy and Biochemistry and in the unit for ELISA technique at Sestre milosrdnice University Hospital Centre. The goal of the study was to explore how students face with stress, how they stand it, and which biochemical indicators point to their behavior. Two groups of students were selected, one group consisting of physically active respondents attending second and third year at the Faculty of Kinesiology, and the other group including students from other faculties with no regular physical activity in their curriculum. The respondents first underwent psychological testing consisting of two tests, Quality of Life Questionnaire and Questionnaire of Stressful Styles, followed by saliva sampling. Sampling was performed according to a standardized procedure using the Salivetta system. The aim was to investigate whether there was any betweengroup difference or association in biochemical indicators or perception of stress, concerning their response and readiness to face stress situations. Considering that continuous physical activity causes chronic stress manifested by reduced cortisol concentrations and elevated sAA concentrations, it was expected that the FK group would have such values of these biochemical markers. In OF group, inverse results or mildly elevated cortisol and lower sAA concentrations compared to FK group were expected, due to the influence of psychic stress present during preparation of exams, presentation of seminar work, etc. Since most literature reports show results only for physically active groups, the aim was to explore a physically inactive group and compare it to the physically active one because psychic stress has the same effect as physical stress, and our expectations had ground in the published studies. Similar studies have been carried out in recent years, such as the one conducted by Van den Bos et al. Concentrations of salivary cortisol positively and strongly correlated in risky situations in men, which was significantly different from poor adverse relationships in risky situations in women ${ }^{22}$. In the study by Wolf et al., the value of salivary cortisol and sAA was compared in healthy children and children with asthma, showing that chronic stress and asthma caused elevated salivary cortisol levels and decreased sAA values in children with asthma compared to healthy children ${ }^{23}$. In the study by Hare et al., salivary cortisol concentrations were measured before and after parachute jump and there was no statistically significant difference in salivary cortisol concentrations between these two groups but elevated cortisol values were obtained after the jump in both groups ${ }^{24}$. In the study by Van Stegeren $e t$ al., participants were exposed to stress by holding their hands for 10-20 minutes in water with ice cubes; men had higher sAA concentration than women, indicating a gender difference, however, it did not reach statistical significance. Salivary cortisol concentrations monitored in the same way showed no effect of gender but were elevated in control group. In women, sAA correlated positively with their workload ${ }^{25}$.

Our study showed that there was no statistically significant difference in sAA concentrations and salivary cortisol concentrations between the $\mathrm{FK}$ and $\mathrm{OF}$ groups. A statistically significant difference was demonstrated by comparing all men and women from both groups, and between men and women within the FK group for sAA concentrations. The values obtained but not expected could be attributed to the small number of study subjects and possible physiological effects in some individuals (menstrual cycle, oral contraceptives, cortisol circadian rhythm, pregnancy, etc.) at low concentrations of the analyte because of which small analytical errors can lead to significant changes in the actual concentration. Also, interpretation of the results was additionally complicated by the lack of reference intervals or existence of reference intervals that differ among literature reports. Although commercially prepared kits were used for determination of sAA and salivary cortisol, sAA determination required 1:201 dilution of samples, which could additionally influence the accuracy of the results obtained at low concentrations. Other studies mainly show negative correlation between sAA and salivary cortisol, i.e. they are inversely proportional, as shown by the results obtained, but this correlation had no statistical significance; we believe that the small number of study subjects was the reason for this. The aim of this study was to link the psychological indicators through two questionnaires that were scored, statistically processed and related to the biochemical stress indicators of salivary cortisol and sAA. However, no statistically significant correlation was obtained although the correlation between these parameters was expected based on the group concept. Hypothetically, FK and OF groups should differentiate their quality of life and respond to stress- 
ful situations such as physical and psychological stress. In the Faculty of Kinesiology students, it was assumed that strong physical activity would be hypothetically accompanied by lower cortisol values and higher amylase values compared to other students who did not have intense physical activity.

In conclusion, this observation established a weak to moderate negative association between salivary cortisol and sAA concentrations, but no statistical significance was demonstrated. Equal connectivity was observed in all students irrespective of physical activity. The best correlation between cortisol and sAA concentrations and highest statistical significance were found in the group of students with moderate physical activity. Perhaps the association would have been stronger if the study group had more than 27 respondents. It was also found that there was no statistically significant correlation between biochemical stress indicators and results obtained by the psychological test method. More active and more positive coping with stressful conditions was observed in students from the Faculty of Kinesiology based on one domain of psychological testing of stressful stress styles. Comparing biochemical and psychological indicators with stress, it was concluded that the two groups of students were equalized and no objective baseline was found for which chronic stress could be attributed to either group. Despite the substantial differences in physical activity, there was no difference between the two student populations. The levels of cortisol and amylase could not be evaluated relative to the reference intervals because the research, though numerous, yields different results for healthy population.

\section{References}

1. Havelka M. Zdravstvena psihologija. Zagreb: Medicinski fakultet Sveučilišta u Zagrebu, 1995. (in Croatian)

2. Martinac M, Bevanda D, Bevanda-Glibo D, Tomić I, Tomić M, Bevanda M, Vasilj I. Psychosocial and clinical characteristics of depressive patients with the diagnosis of metabolic syndrome. Alcohol Psychiatry Res. 2016;52:17-32.

3. Wolf JM, Nicholls E, Chen E. Chronic stress, salivary cortisol, and $\alpha$-amylase in children with asthma and healthy children. Biol Psychol. 2008;78:20-8. doi: 10.1016/j.biopsycho.2007.12.004

4. Šupe S, Poljaković Z, Kondić Lj, Unušić L, Alvir D. Neurološke osnove stresa i rizik razvoja moždanog udara. Neurol Croat. 2011;60(1):21-8. (in Croatian)
5. http://www.zdravljeizprirode.hr/tema.php?id=19; accessed 25 April 2014.

6. Hudek-Knežević J, Kardum I. Psihosocijalne odrednice tjelesnog zdravlja. Stres i tjelesno zdravlje. Naklada Slap, Sveučilište u Rijeci, 2005. (in Croatian)

7. Yia TC, Moochhalab S. Mini-Review Article - Current Opinion on Salivary Biomarkers as a Measurement for Stress and Fatigue. The Open Biomarkers Journal. 2013;6:9-14.

8. Arhakis A, Karagiannis V, Kalfas S. Salivary alpha-amylase activity and salivary flow rate in young adults. Open Dent J. 2013;7:7-15. doi: 10.2174/1874210601307010007

9. Scannapieco FA, Torres G, Levine MJ. Salivary $\alpha$-amylase: role in dental plaque and caries formation. Crit Rev Oral Biol Med. 1993;4:301-7.

10. Dorn LD, Lucke JF, Loucks TL, Berga SL. Salivary cortisol reflects serum cortisol: analysis of circadian profiles. Ann Clin Biochem. 2007;44:281-4.

11. Aardal E, Holm A. Cortisol in saliva - reference ranges in relation to cortisol in serum. Eur J Clin Chem Clin Biochem. 1995;33:927-32.

12. Anizan S, Huestis MA. The potential role of oral fluid in antidoping testing. Clin Chem. 2014;60(2):307-22. doi: 10.1373/ clinchem.2013.209676

13. Kostanjšak L, Zdunić D. The role of thrombocyte serotonin system and some thrombocyte characteristics in treatment of depressive patients with cardiovascular diseases. Alcohol Psychiatry Res. 2017;53:33-44. doi: 10.20471/apr.2017.53.01.04

14. Hellhammer DH, Wust S, Kudielka BM. Salivary cortisol as a biomarker in stress research. Psychoneuroendocrinology. 2009;34:163-71. doi: 10.1016/j.psyneuen.2008.10.026

15. Instructions for use. EUROIMMUN Medizinische Labordiagnostika AG, AlphaAmylase Saliva ELISA, revised 16 January 2012.

16. Instructions for use. EUROIMMUN Medizinische Labordiagnostika AG, Cortisol Saliva ELISA, revised 4 April 2012.

17. Carver C, Scheier MF, Weintraub JK. Assessing coping strategies: a theoretically based aproach. J Pers Soc Psychol. 1989; 56:267-83.

18. Belak Kovačević S. Stres i suočavanje kod ovisnika o opijatima, Zagreb: Filozofski fakultet Sveučilišta u Zagrebu; 2004. (in Croatian)

19. Vurnek-Živković M. Psihološki status i percepcija bolesti u bolesnika s melanomom. Zagreb: Medicinski fakultet Sveučilišta u Zagrebu, 2011. (in Croatian)

20. WHOQOL User Manual. Geneva: World Health Organization, Division of Metal Health and Prevention of Substance Abuse, 1998.

21. Glažar I, Urek MM, Kuiš D, Prpić J, Mišković I, Pavičić DK, Pezelj-Ribarić S. Salivary flow rate, oral yeast colonization and dental status in institutionalized and non-institutionalized elderly. Acta Clin Croat. 2016;55:390-5. 
22. Van den Bos R, Taris R, Scheppink B, deHaan L, Verster JC. Salivary cortisol and alpha-amylase levels during an assessment procedure correlate differently with risk taking measures in male and female police recruits. Behav Neurosci. 2014;7:1-10. doi: 10.3389/fnbeh.2013.00219

23. Wolf JM, Nicholls E, Chen E. Chronic stress, salivary cortisol, and $\alpha$-amylase in children with asthma and healthy children. Biol Psychol. 2008;78:20-8. doi: 10.1016/j.biopsycho.2007.12.004
24. Hare AO, Wetherell MA, Smith MA. State anxiety and cortisol reactivity to skydiving in novice versus experienced skydivers. Physiol Behav. 2013;118:40-4. doi: 10.1016/j.physbeh.2013.05.011

25. Van Stegeren A, Wolf OT, Kindt M. Salivary alpha amylase and cortisol responses to different stress tasks: impact of sex. Int J Psychophysiol. 2008;69:33-40. doi: 10.1016/j.ijpsycho.2008.02.008

Sažetak

\section{KORELACIJA BIOKEMIJSKIH INDIKATORA STRESA U SLINI I PSIHOLOŠKIH INDIKATORA}

\section{Crnković, M. Peco i J. Gelo}

Slina je tjelesna tekućina složenog sastava koja ima razne funkcije u usnoj šupljini. Središnji živčani sustav ima najznačajniju ulogu u regulaciji salivacije. Slina kao uzorak pogodna je zbog jednostavnosti uzorkovanja, a u njoj se analiti nalaze u slobodnom, tj. aktivnom obliku. Stres je stanje u kojem je poremećena unutarnja (psihofiziološka) ravnoteža organizma. Aktivira osovinu hipotalamus-hipofiza-kora nadbubrežne žlijezde pa je salivarni kortizol indikator slobodnog kortizola, dobro korelira sa serumskom vrijednošću i odražava slobodnu frakciju koja je biološki aktivna. Istodobno stresna stanja stimuliraju simpatički neuronski sustav, što uzrokuje promjenu lučenja slinovne alfa-amilaze iz žlijezda slinovnica. Hipoteza ovoga istraživanja bila je da su studenti sa svakodnevnom intenzivnom fizičkom aktivnošću izloženi kroničnom stresu u odnosu na druge studente koji imaju minimalne fizičke aktivnosti. U istraživanje je bilo uključeno 54 zdravih dobrovoljaca, studenata Sveučilišta u Zagrebu, podijeljenih u dvije skupine; jednu skupinu dobrovoljaca činili su fizički aktivni dobrovoljci $(n=27)$ s Kineziološkog fakulteta, a drugu skupinu činili su fizički neaktivni dobrovoljci $(n=27)$ s ostalih fakulteta. Ispitanici su najprije bili podvrgnuti psihološkom testiranju koje se sastojalo od dva upitnika, Upitnik kvalitete života i Upitnik stilova suočavanja sa stresom te je potom izvršeno uzorkovanje sline. Usporedbom biokemijskih i psiholoških pokazatelja u odnosu na stres zaključeno je da su dvije skupine studenata izjednačene te nije nađeno objektivno uporište po kojem se jednoj skupini mogao pripisati kronični stres. Unatoč bitno različitim fizičkim aktivnostima nije utvrđena razlika između dviju studentskih populacija.

Ključne riječi: slina; stres, fiziološki; stres, psihološki; živčani sustav; hidrokortizon; amilaza; žlijezde slinovnice; vježbanje; psibološko testiranje; ankete i upitnici 